\title{
A modern Cosmas and Damian: Sir Roy Calne and Thomas Starzl receive the 2012 Lasker Debakey Clinical Medical Research Award
}

C osmas and Damian, the patron saints of surgeons, were twin brothers who dedicated their lives to healing the sick (Figure 1). They are most revered for performing the first transplant operation, when they replaced the gangrenous leg of the sacristan Justinian with one from a recently deceased soldier. In the 1940s and 1950s, when Thomas Starzl and Sir Roy Calne (Figure 2) were training to be surgeons, successful transplantation was still in the domain of the miraculous; in fact, both Calne and Starzl had been told that the procedure was impossible. However, within a period of 30 years, they were able to overcome surgical and biological obstacles to develop liver transplantation procedures that have saved the lives of thousands of patients and made the transplantation of multiple organs a reality.

In the late 1950s, the inability to perform a liver transplant meant that liver diseases were often fatal. The liver is critical to a wide variety of physiological processes. It removes and breaks down toxins in the blood, generates biochemicals necessary for digestion, stores glycogen and vitamins, and produces plasma proteins (such as clotting factors) and hormones (such as angiotensin and cholesterol). Diseases or damage that interfere with liver function can lead to a multitude of abnormal physiological processes. Liver damage can be inflicted in various ways, including infections such as hepatitis, exposure to alcohol or drugs, cirrhosis, and cancer. Inherited disorders can cause pediatric liver diseases such as biliary atresia, Wilson's disease, Alagille syndrome, progressive familial intrahepatic cholestasis, Langerhans cell histiocytosis, and $\alpha 1$-antitrypsin deficiency. Once the liver has sustained severe and permanent damage, a patient's only option may be the transplantation techniques pioneered by Calne and Starzl.

\section{Mythical medicine}

Organ and tissue transplantation was originally the medicine of mythology. Many cultures venerate chimeric gods and heroes, and examples can be found in a variety of religious texts, including the Old Testament, the Rg Veda, and the Lieh-Tzu (1). However, the idea of treating a disease by replacing the injured tissue or organ was a logical one to the first surgeons. Tooth transplantation was practiced in ancient Egypt, Greece, and Rome and in preColombian North and South America (2, 3 ). As early as $800 \mathrm{BC}$, the Indian surgeon Sushruta Samhita reported the use of skin autografts (1). These first surgeons realized early on that there were two primary problems to be solved to make organ transplantation practical: the first was the development of appropriate surgical techniques, and the second was the rejection of foreign tissue. Gaspare Tagliacozzi, a 16th century Italian surgeon considered to be the father of plastic surgery, may have been the first to recognize the problem of immune rejection in allografts when he observed that "the singular character of the individual entirely dissuades us from attempting [tis- sue transplantation] on another person" (4). Overcoming the surgical and immunological barriers of transplantation would consume Starzl and Calne for the greater part of their careers.

\section{“It can't be done"}

In 1950, Calne was a medical student at Guy's Hospital when he began thinking about transplant surgery. During training, students were allocated patients for whom they were personally responsible, presenting their cases during rounds and serving as patient advocates. A young patient, close to Calne's age, was dying of kidney failure, and Calne was told to make him as comfortable as possible since he would be dead within two weeks. Calne recalled, "That was a pretty awful shock for me, thinking about the patient. I said, 'Could he not have a graft of a kidney?,' thinking that you can have a graft of a rose or a graft of an apple tree." The

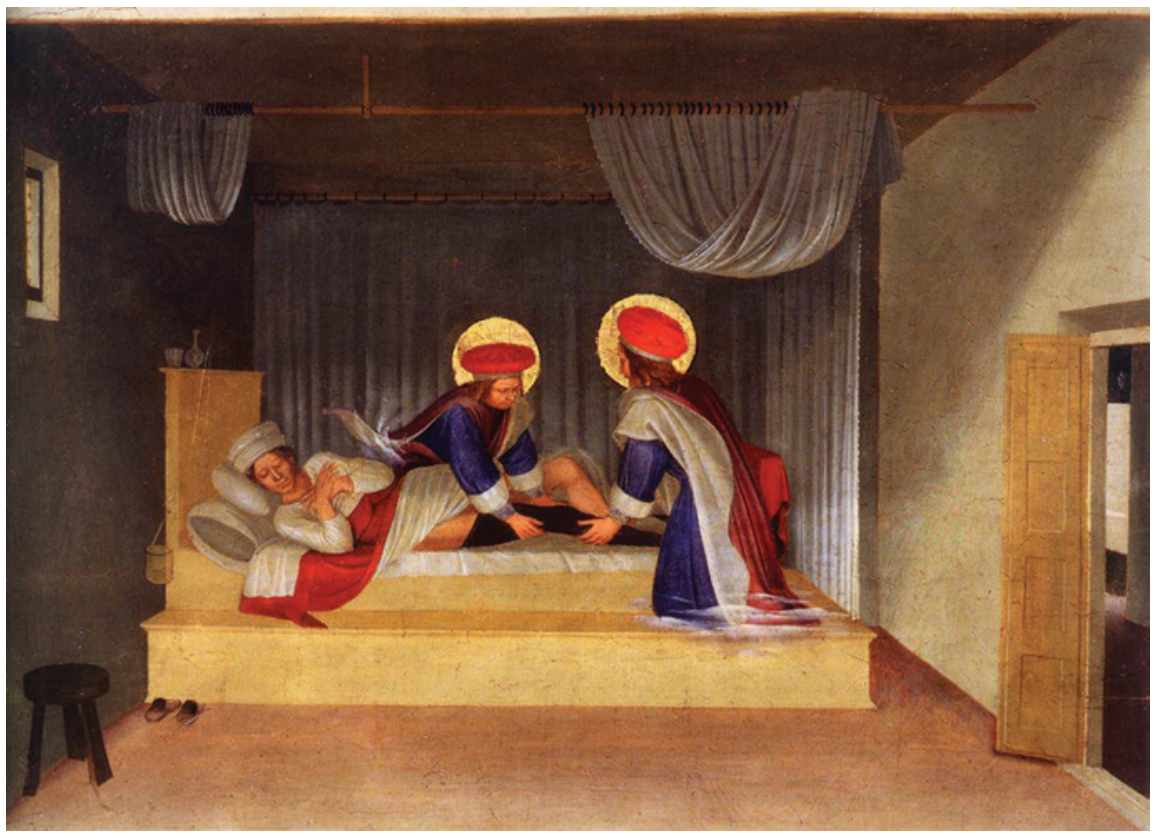

\section{Figure 1}

The healing of Justinian by Saint Cosmas and Saint Damian, Fra Angelico, 1438-1440. Image in the public domain. 

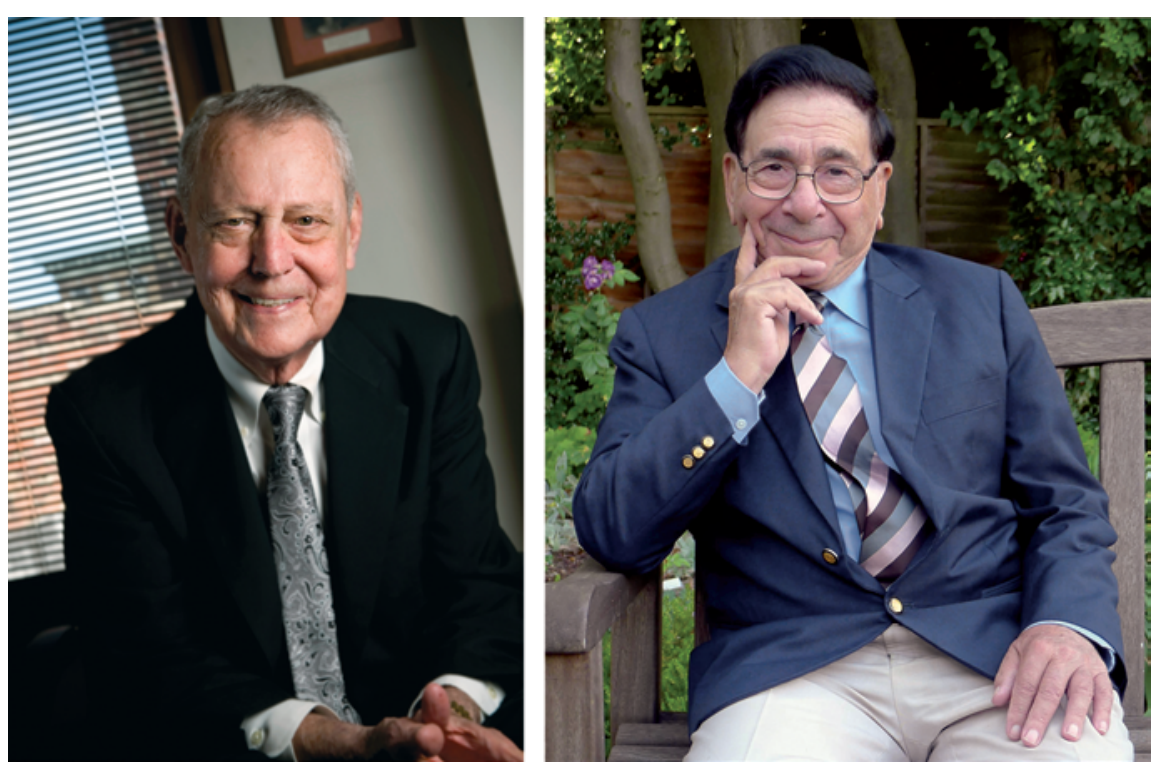

Figure 2

Thomas Starzl (left) and Sir Roy Calne (right), winners of the 2012 Lasker Debakey Clinical Medical Research Award.

attending physician told him no. When Calne asked why, he was told, "It can't be done." After rounds, Calne and his colleagues discussed the possibility of kidney transplantation. "We knew what a kidney looked like, we knew it was joined by an artery and a vein, we knew it drained urine into the bladder, and we couldn't figure out why it couldn't be grafted from a surgical point of view. Of course we were right in that assumption . . . but [with respect to] the other, biological, side of organ transplantation, we, as medical students, had no concept at all. I suppose my whole life's career has been involved in trying to understand and manipulate the biology of rejection,” said Calne.

Calne completed his medical training in 1952 and served in the Royal Army Medical Corps from 1953 to 1955 . He returned to England and was hired by Wilfrid Le Gros Clark to teach anatomy at Oxford University. While at Oxford, Calne's younger brother, Donald, a medical student at the time, suggested that he come to a lecture by Peter Medawar.

Medawar and Sir Frank MacFarlane Burnet had developed an overall theory of the immunological nature of self and the idea of immunological tolerance. Burnet hypothesized that the "self" of the host body was not preprogrammed, but rather actively defined during embryogenesis through the interaction of immune cells with the tissues of the embryo (5). This hypothesis implied that tolerance could be induced if donor tissues were introduced to the embryo within a particular developmental time frame (6). Burnet was proven correct when Medawar showed that mouse embryos receiving cells from a different mouse strain accepted tissue grafts from the strain later on in life, while rejecting grafts from other strains. These experiments were the first to demonstrate that it was possible to manipulate the immune system (7). "At the end of this fascinating lecture," recalled Calne, "when it came to question time, one of the students asked him if there was any possibility that his work would have applications in the treatment of patients ... I don't think he was often asked that question, because after thinking about it for a moment or two, he smiled and said, 'Absolutely none.”'

\section{Proposing the impossible}

Thomas Starzl entered medical school at Northwestern University in 1947. After three years of medical school, he took a year off to do research with Horace Magoun, studying the processing of sensory stimuli by the reticular formation (8-12). His work in Magoun's laboratory earned Starzl a Ph.D. in neurophysiology and an M.A. in anatomy. After completing medical school in 1952, Starzl enrolled in a surgical training program. During his residency, discus- sions of the liver's double blood supply sparked Starzl's interest in determining the role of portal blood in whole-body metabolism. To study this problem, he developed surgical procedures to replace the liver in dogs (13-19).

In 1958, Starzl returned to Northwestern, at which time he received two awards to fund his research in liver transplantation. One was a five-year grant from the NIH, and the other was a fellowship with the Markle Scholars-in-Medicine program. The Markle fellowship was designed to bring innovative young doctors into academic medicine. Each candidate was supposed to propose a project that would require a lifetime of effort. "Liver transplantation was perfect," said Starzl. "Not only had there not been any [successful orthotopic] organ transplants at that time, but the liver was the most difficult organ." After receiving the Markle Fellowship, Starzl remained on Northwestern's surgical faculty for four years and continued refining surgical transplantation techniques $(20,21)$.

\section{New approaches in immunosuppression}

Meanwhile, Calne, after qualifying as a surgeon, took a position at the Royal Free Hospital in London. Undeterred by the prevailing skepticism about the clinical utility of organ transplantation, Calne began conducting experimental kidney transplants in dogs. At the time, irradiation was the primary method used to suppress transplant rejection; however, the procedure was highly toxic and rarely successful. Based on reports from Schwartz and Dameshek showing that 6-mercaptopurine suppressed antibody formation, Calne began experimenting with immunosuppressive drugs (22-24). In 1960, Calne - and, independently, Charles Zukoski in Virginia reported that treatment with 6-mercaptopurine could keep dog kidney transplant recipients alive for several weeks, marking the first successful use of chemical immunosuppressants in transplantation (25-27).

The results from Calne's studies were so promising that he was encouraged by Medawar to continue his research. Calne was awarded a Harkness Fellowship to study at Harvard's Peter Bent Brigham Hospital with Francis Moore and Joseph Murray. While in Boston, he began collaborating with George Hitchings and Gertrude Elion of Burroughs-Wellcome Laboratories, who synthesized 6-mercaptopurine. One of the compounds they suggested 

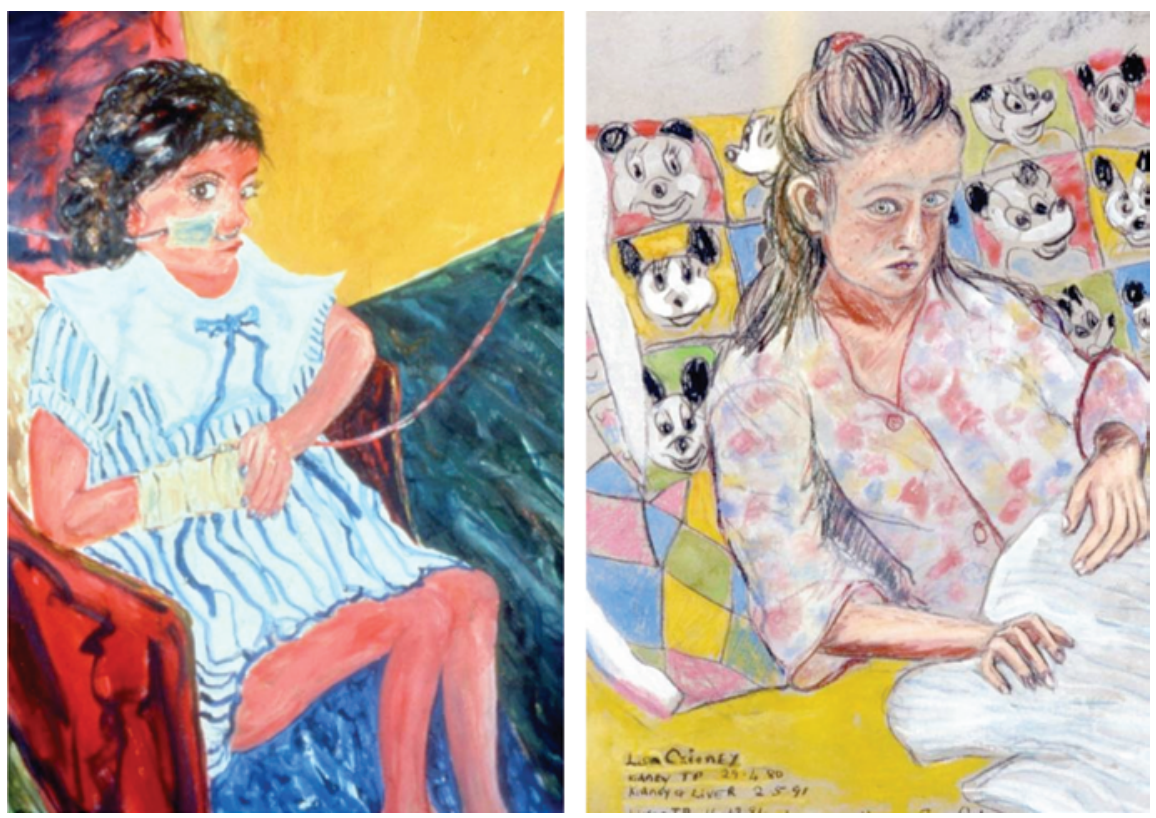

Figure 3

Left: Child after a liver transplant (1989). Right: Lisa Cairney 1992 - Underwent Two Liver and Kidney Transplantations at Addenbrooke's Hospital. Reproduced with permission of Sir Roy Calne. In an August 8 interview, Calne said, "I've never not painted and drawn, but I became much more interested in what I tried to do with the painting when I had an English artist as a liver transplant patient, John Bellany. In the ICU, when he came off the ventilator, he asked for paints and paper. He couldn't lift his head. He had to use a mirror to paint himself. He did 60 paintings of himself recovering from the liver transplant in three weeks and filled his room. He gave me some lessons, and we became friends. Once, he painted himself in the image of St. Sebastian, being tortured by surgeons. In one of the lessons, he painted me and I painted him. My perception of him and his perception of himself were so different that I thought it would be a very interesting subject to paint my patients. We used to do a lot of transplants of livers in children, and I found that children rather liked the process of image making and could join in ... we would color the paintings together and criticize each other's drawings."

testing, azathioprine (Imuran), had a better therapeutic index than 6-mercaptopurine and was used in the first series of human kidney transplants using immunosuppression in $1961(25,28-31)$.

\section{The first liver transplants}

Starzl accepted a position as an associate professor of surgery at the University of Colorado in 1962, where he obtained a supply of azathioprine to develop clinical immunosuppression protocols and began human kidney transplant surgeries. In 1963 , he reported that a combination of azathioprine and prednisone in humans was able to prevent and even reverse rejection $(32,33)$. This immunosuppressant combination was so successful that 50 more renal transplant programs were established in the United States by 1964.

Buoyed by the success with kidneys, Starzl performed five human liver transplants between March and October of 1963. The maximum survival was 21 days; however, the liver grafts did not fail due to rejection, but rather because of surgical complications (34). Two more surgeons made single, failed attempts in Boston and Paris, and in the wake of these, the medical community agreed to a moratorium on liver transplants.

Between the fall of 1963 and the summer of 1967, Starzl and Calne worked to address problems in surgical technique and immune suppression that contributed to the previous failures. In 1964, Starzl directed the first extensive trial of tissue matching, based on methods to detect tissue antigens developed by Paul Terasaki in the early 1960s (32, 35-37). Surgical improvements included extracorporeal perfusion to preserve donor organs and infection containment (38-43). To improve immunosuppression, Starzl began using antilymphocyte globulin (ALG) as an adjunct to azathioprine and prednisone $(44,45)$.
Calne, now at the University of Cambridge, began studying liver transplantation in pigs, which frequently accepted grafts from unrelated pigs without any immune suppression (46-48). The grafts often underwent histological and biochemical rejection, which resolved spontaneously. Further, the porcine liver graft could protect other tissues from the same donor from rejection. These results foreshadowed future findings in humans.

In 1967, Starzl reopened the Denver liver transplant program. Survival times for patients treated with the azathioprine/ prednisone/ALG regimen began to exceed one year $(49,50)$. In 1968, Calne performed the first liver transplant in Europe and opened the transplantation program in Cambridge (51). Three more European liver transplant centers were opened in the early 1970s. A trans-Atlantic alliance among these first centers allowed for the development of liver transplant protocols that are still the standard today.

\section{The experiment becomes standard}

Further research into immunosuppressive drug regimens continued to improve organ transplant outcomes. Calne began testing cyclosporin $\mathrm{A}$, an immunosuppressive compound even more potent than azathioprine, that was particularly effective in liver, kidney, and heart transplants and in skin grafts in several animal models. Initial trials in humans showed that high doses of cyclosporine could cause nephrotoxicity; however, with careful dosage adjustments, the one-year survival rate for kidney transplant patients increased from $50 \%$ to $80 \%(52-54)$. Cyclosporin was the first compound to specifically inhibit lymphocytes and was the first single drug that could control organ rejection. Its introduction changed the perception of organ transplantation from a dangerous experiment to a clinically feasible undertaking (55). Starzl began using a combination of cyclosporine and prednisone in liver transplant patients (56). By the late 1970 s, the majority of liver transplant patients were surviving longer than a year. Based on these successes, three more liver transplantation centers opened in Europe.

In 1983, US Surgeon General C. Everett Koop convened a Consensus Development Conference for liver transplantation, which concluded that liver transplantation was no longer an experimental procedure and could now be considered a standard clinical service (57). The number of hospitals offering the procedure exploded. By 1989, 
Starzl wrote in the New England Journal of Medicine, "The conceptual appeal of liver transplantation is so great that the procedure may come to mind as a last resort for virtually every patient with lethal hepatic disease" (58).

\section{Moving toward "almost-tolerance"}

Calne and Starzl continued to seek new immunosuppressive agents that were potent enough to fight rejection, but also caused fewer side effects. In 1989, Starzl, now at the University of Pittsburgh, introduced FK-506 (Tacrolimus) $(59,60)$. FK-506 was effective in patients who were rejecting organs while taking the standard cyclosporine/prednisone/ ALG regimen and was fast-tracked for approval by the FDA in 1993. Calne began working with rapamycin (Sirolimus) in 1989, and the European Rapamycin Study group had success in the clinic using it as a stand-alone drug (61-63). The antibody alemtuzumab (Campath 1H), developed by Herman Waldmann at the University of Cambridge, was initially used to treat rejection, but then became a preemptive therapeutic used to avoid rejection altogether (64-68).

The ultimate goal in developing new immunosuppressive therapies is to improve the lives of transplant patients by reducing side effects and costs while maintaining tolerance of donor organs. Calne's early observation of liver tolerance in the pig suggested that immunological tolerance would only be achieved by active engagement of the recipient's immune system with the donor tissue. Calne hypothesized that a window of opportunity for immunological engagement (WOFIE) was an essential step in the development of tolerance; therefore, recipient immunosuppression should be minimized (69).

Transplant patients themselves began conducting their own experiments when they stopped taking immunosuppressive drugs without telling their doctors. Many of these patients did not suffer from graft rejection, achieving an operationally tolerant state. The Pittsburgh transplant group conducted a study of the risks and benefits of weaning liver transplant recipients off immunosuppression and concluded that, with careful monitoring, the practice was relatively safe $(70,71)$. However, the mechanisms underlying tolerance were still unclear. In 1992, Starzl reported that a small population of donor leukocytes persisted in the livers and kidneys of long- surviving organ recipients. The organ engraftment in the patients that stopped taking their immunosuppressive drugs and in Calne's porcine liver transplants appeared to be caused by donor leukocyte chimerism (72-74). The role of microchimerism in graft acceptance is still highly controversial, as it is not perfectly correlated with graft acceptance, and the effect of microchimerism appears to be organ dependent (75-77). "There's still room for improvement in immunosuppression," said Starzl, "particularly in developing better strategies for using good drugs that are already there."

The studies outlined above illustrate the rapid evolution of the science of immunosuppression. In the 1950s, full-body irradiation, a highly toxic treatment, was used to suppress the immune system. The work of Starzl and Calne in the development of immunosuppressive drug regimens allowed for long-term survival after transplantation, improved the quality of life for transplant patients, and made possible the transplant of other organs, including the heart, pancreas, lungs, and intestines.

\section{The future of transplantation}

The main problem in transplantation is now the lack of donor organs and the ethical issues that accompany this shortage. In the United States, more than 15,000 patients are awaiting a donor liver, and both Calne and Starzl have advocated for better organ donation programs. Calne, a gifted artist, uses his artwork to promote awareness of transplantation. Many of his paintings depict transplant surgery and transplant patients (Figure 3).

Organ transplantation, once considered impossible, has now become a standard therapy. According to the National Network of Organ Donors, the number of Americans living with a liver graft in 2009 was more than 50,000. Furthermore, greater than $70 \%$ of liver transplant patients survive more than five years. Despite the backdrop of constant skepticism, Calne and Starzl persevered, converting liver transplantation from a divinely inspired miracle into a marvel of science that saves the lives of thousands of patients each year.

\section{Jillian Hurst}

1. Hauben DJ. Sushruta Samhita (Sushruta'a Collection) (800-600 B.C.?). Pioneers of plastic surgery. Acta Chir Plast. 1984;26(2):65-68.

2. Guthrie D. A History OfMedicine. Philadelphia, Pennsylvania, USA: J.B. Lippincott \& Company; 1946.
3. Peer LA. Transplantation OfTissues. Baltimore, Maryland, USA: Williams \& Wilkins Co; 1955.

4. Dausset J, Rapaport FT. Human Transplantation. New York, New York, USA: Grune and Stratton; 1968.

5. Park HW. Germs, hosts, and the origin of Frank Macfarlane Burnet's concept of "self " and "tolerance," 1936-1949. J Hist Med Allied Sci. 2006; 61(4):492-534.

6. Burnet FM, Fenner F. The Production Of Antibodies. Melbourne, Australia: Macmillan; 1949.

7. Billingham RE, Brent L, Medawar PB. 'Actively acquired tolerance' of foreign cells. 1953. Transplantation. 2003;76(10):1409-1412.

8. Starzl TE, Magoun HW. Organization of the diffuse thalamic projection system. J Neurophysiol. 1951;14(2):133-146

9. Starzl TE, Taylor CW, Magoun HW. Ascending conduction in reticular activating system, with special reference to the diencephalon. J Neurophysiol. 1951;14(6):461-477.

10. Starzl TE, Taylor CW, Magoun HW. Collateral afferent excitation of reticular formation of brain stem. J Neurophysiol. 1951;14(6):479-496.

11. Starzl TE, Niemer WT, Dell M, Forgrave PR. Cortical and subcortical electrical activity in experimental seizures induced by metrazol. J Neuropathol Exp Neurol. 1953;12(3):262-276.

12. Starzl TE, Whitlock DG. Diffuse thalamic projection system in monkey. $J$ Neurophysiol. 1952;15(6):449-468.

13. Starzl TE, Kaupp HA, Brock DR, Lazarus RE, Johnson RV. Reconstructive problems in canine liver homotransplantation with special reference to the postoperative role of hepatic venous flow. Surg Gynecol Obstet. 1960;111:733-743.

14. Starzl TE, Kaupp HA, Brock DR, Butz GW, Linman JW. Homotransplantation of multiple visceral organs. Am J Surg. 1962;103:219-229.

15. Starzl TE, Kaupp HA Jr, Brock DR, Linman JW. Studies on the rejection of the transplanted homologous dog liver. Surg Gynecol Obstet. 1961;112:135-144.

16. Starzl TE, Butz GW Jr, Brock DR, Linman JT, Moss WT. Canine liver homotransplants. The effect of host and graft irradiation. Arch Surg. 1962;85:460-464.

17. Kukral JC, Littlejohn MH, Williams RK, Pancner RJ, Butz GW Jr, Starzl TE. Hepatic function after canine liver transplantation. Arch Surg. 1962;85:157-165.

18. Brock DR, Starzl TE. Histopathologic alterations associated with the transplanted homologous dog liver. Exp Mol Pathol. 1962;1:187-203.

19. Starzl TE, Butz GW Jr. Surgical physiology of the transplantation of tissues and organs. Surg Clin North Am. 1962;42:55-67.

20. Starzl TE, Kaupp HA. Mass homotransplantation of abdominal organs in dogs. Surg Forum. 1960;11:28-30.

21. Starzl TE, Butz GW, Munger DH. A technique for portacaval transposition. J Surg Res. 1961; $1(3): 218-220$

22. Schwartz R, Stack J, Dameshek W. Effect of 6-mercaptopurine on antibody production. Proc Soc Exp Biol Med. 1958;99:164-167.

23. Schwartz R, Dameshek W. Drug-induced immunological tolerance. Nature. 1959;183(4676):1682-1683.

24. Meeker WR Jr, Condie RM, Good RA, Varco RL. Alteration of the homograft response by antimetabolites. Ann N Y Acad Sci. 1960;87:203-213.

25. Calne RY. Inhibition of the rejection of renal homografts in dogs by purine analogues. Transplant Bull. 1961;28:65-81.

26. Zukoski CF, Lee HM, Hume DM. The prolongation of functional survival of canine renal homografts by 6-mercaptopurine. Surg Forum. 1960;11:470-472.

27. Calne RY. The rejection of renal homografts. Inhibition in dogs by 6-mercaptopurine. Lancet. 1960;1(7121):417-418.

28. Calne RY, Murray JE. Inhibition of the rejection of 
renal homografts in dogs by Burroughs Wellcome 57-322. Surg Forum. 1961;12:118-120.

29. Murray JE, Merrill JP, Harrison JH, Wilson RE, Dammin GJ. Prolonged survival of human-kidney homografts by immunosuppressive drug therapy. NEngl J Med. 1963;268:1315-1323.

30. Murray JE, Balankura O, Greenberg JB, Dammin GJ. Reversibility of the kidney homograft reaction by retransplantation and drug therapy. Ann NY Acad Sci. 1962;99:768-780.

31. Merrill JP, Murray JE, Takacs FJ, Hager EB, Wilson RE, Dammin GJ. Successful transplantation of kidney from a human cadaver. JAMA. 1963;185:347-353

32. Starzl TE. Experience In Renal Transplantation. Philadelphia, Pennsylvania, USA: Saunders; 1964.

33. Starzl TE, Marchioro TL, Waddell WR. The reversal of rejection in human renal homografts with subsequent development of homograft tolerance. Surg Gynecol Obstet. 1963;117:385-395.

34. Starzl TE, Marchioro TL, Vonkaulla KN, Hermann G, Brittain RS, Waddell WR. Homotransplantation of the liver in humans. Surg Gynecol Obstet. 1963; 117:659-676.

35. Starzl TE, et al. Chronic survival after human renal homotransplantation. Lymphocyte-antigen matching, pathology and influence of thymectomy. Ann Surg. 1965;162(4):749-787.

36. Terasaki PI, et al. Serotyping for homotransplantation. V. Evaluation of a matching scheme. Transplantation. 1966;4(6):688-699.

37. Terasaki PI, et al. Serotyping for homotransplantation. Vii. Selection of kidney donors for thirty-two recipients. Ann N Y Acad Sci. 1966;129:500-520.

38. Marchioro TL, Waddell WR, Starzl TE. Use of extracorporeal cadaver perfusion for preparation of organ homografts. Surg Forum. 1963;14:174-176.

39. Calne RY, Pegg DE, Pryse-Davies J, Brown FL. Renal preservation by ice-cooling: an experimental study relating to kidney transplantation from cadavers. Br Med J. 1963;2(5358):651-655.

40. Calne RY, Loughridge LW, Pryse-Davies J, Brown FL. Renal transplantation in man: a report of five cases, using cadaveric donors. $\mathrm{Br}$ Med J. 1963;2(5358):645-651.

41. Calne RY. Kidney transplantation. Biochem Clin. 1963;2:497-504

42. Calne RY. Inhibition of the rejection of renal homografts in dogs by drugs. Ann R Coll Surg Engl. 1963;32:281-302

43. Starzl TE, et al. Immunosuppression after experimental and clinical homotransplantation of the liver. Ann Surg. 1964;160:411-439.

44. Huntley RT, et al. Use of anti-lymphocyte serum to prolong dog homograft survival. Surg Forum.
1966;17:230-233.

45. Starzl TE, Marchioro TL, Faris TD, McCardle RJ, Iwaski Y. Avenues of future research in homotransplantation of the liver with particular reference to hepatic supportive procedures, antilymphocyte serum, and tissue typing. Am J Surg. 1966;112(3):391-400.

46. Cordier G, et al. [Orthotopic liver graft in pigs. 1st results]. Mem Acad Chir (Paris). 1966;92(27):799-807.

47. Garnier $\mathrm{H}$, et al. [Liver transplantation in the pig: surgical approach]. C R Acad Sci Hebd Seances Acad SciD. 1965;260(21):5621-5623.

48. Calne RY, et al. Observations of orthotopic liver transplantation in the pig. $\mathrm{Br}$ Med $J$. 1967;2(5550):478-480.

49. Starzl TE, Marchioro TL, Porter KA. Progress in homotransplantation of the liver. Adv Surg. 1966;2:295-370.

50. Starzl TE, Marchioro TL, Porter KA, Brettschneider L. Homotransplantation of the liver. Transplantation. 1967;5(4):790-803

51. Calne RY, Williams R. Liver transplantation in man. I. Observations on technique and organization in five cases. Br Med J. 1968;4:535-540.

52. Calne RY, et al. Cyclosporin A initially as the only immunosuppressant in 34 recipients of cadaveric organs: 32 kidneys, 2 pancreases, and 2 livers. Lan cet. 1979;2(8151):1033-1036.

53. Calne RY, White DJ, Rolles K, Smith DP, Herbertson BM. Prolonged survival of pig orthotopic heart grafts treated with cyclosporin A. Lancet. 1978;1(8075):1183-1185.

54. Borel JF, Feurer C, Gubler HU, Stahelin H. Biological effects of cyclosporin A: a new antilymphocytic agent. Agents Actions. 1976;6(4):468-475.

55. Colombo D, Ammirati E. Cyclosporine in transplantation - a history of converging timelines. J Biol Regul Homeost Agents. 2011;25(4):493-504.

56. Starzl TE, Klintmalm GB, Porter KA, Iwatsuki $\mathrm{S}$, Schroter GP. Liver transplantation with use of cyclosporin a and prednisone. $N$ Engl J Med. 1981;305(5):266-269.

57. NIH. National Institutes of Health Consensus Development Conference Statement: liver transplantation - June 20-23, 1983. Hepatology. 1984;4(1 suppl):107S-110S

58. Starzl TE, Demetris AJ, Van Thiel D. Liver transplantation (1). NEnglJ Med. 1989;321(15):1014-1022.

59. Venkataramanan R, et al. Biopharmaceutical aspects of FK-506. Transplant Proc. 1987;19(5 suppl 6):30-35.

60. Starzl TE, Todo S, Fung J, Demetris AJ, Venkataramman R, Jain A. FK 506 for liver, kidney, and pancreas transplantation. Lancet. 1989;2(8670):1000-1004.

61. Calne RY, et al. Rapamycin for immunosuppression in organ allografting. Lancet. 1989;2(8656):227.

62. Calne RY. The development of immunosuppression: the rapamycin milestone. Transplant Proc. 2003;35(3 suppl):15S-17S

63. Groth CG, et al. Sirolimus (rapamycin)-based therapy in human renal transplantation: similar efficacy and different toxicity compared with cyclosporine. Sirolimus European Renal Transplant Study Group. Transplantation. 1999;67(7):1036-1042.

64. Hale $\mathrm{G}$, et al. Removal of T cells from bone marrow for transplantation: a monoclonal antilymphocyte antibody that fixes human complement. Blood. 1983;62(4):873-882.

65. Hale G, et al. Remission induction in non-Hodgkin lymphoma with reshaped human monoclonal antibody CAMPATH-1H. Lancet. 1988; 2(8625):1394-1399.

66. Waldmann $\mathrm{H}$, et al. Monoclonal antibodies for immunosuppression. Prog Allergy. 1988;45:16-30.

67. Friend PJ, et al. Successful treatment of renal allograft rejection with a humanized antilymphocyte monoclonal antibody. Transplant Proc. 1995;27(1):869-870.

68. Knechtle SJ, et al. FN18-CRM9 immunotoxin promotes tolerance in primate renal allografts. Transplantation. 1997;63(1):1-6.

69. Calne R. WOFIE hypothesis: some thoughts on an approach toward allograft tolerance. Transplant Proc. 1996;28(3):1152.

70. Mazariegos GV, Reyes J, Marino I, Flynn B, Fung JJ, Starzl TE. Risks and benefits of weaning immunosuppression in liver transplant recipients: long-term follow-up. Transplant Proc. 1997;29(1-2):1174-1177.

71. Calne R, Watson CJ. Some observations on prope tolerance. Curr Opin Organ Transplant. 2011;16(4):353-358

72. Starzl TE, et al. Cell migration and chimerism after whole-organ transplantation: the basis of graft acceptance. Hepatology. 1993;17(6):1127-1152.

73. Starzl TE. Chimerism and tolerance in transplantation. Proc Natl Acad Sci U S A. 2004; 101(suppl 2):14607-14614.

74. Starzl TE, Zinkernagel RM. Antigen localization and migration in immunity and tolerance. $N$ EnglJ Med. 1998;339(26):1905-1913.

75. Mathew JM, Leventhal JR, Miller J. Microchimerism in promoting graft acceptance in clinical transplantation. Curr Opin Organ Transplant. 2011;16(4):345-352

76. Sahota A, Gao S, Hayes J, Jindal RM. Microchimerism and rejection: a meta-analysis. Clin Transplant. 2000;14(4 pt 1):345-350.

77. Saraji A, et al. Microchimerism and renal transplantation: doubt still persists. Transplant Proc. 2007;39(4):948-950. 